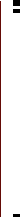

\&konomi هisnis

Volume 25, Nomor 2, Oktober 2020 (95-107)

ISSN 0853-7283 (Print), 2528-0503 (Online)

Available on-line at: http://journal2.um.ac.id/index.php/ekobis

\section{Bagaimana Penggunaan Intuisi Dinilai oleh Manajer Pembelian? Sebuah Studi Berdasarkan Perspektif Karyawan Industri Manufaktur}

\author{
Ariel Nian Gani', Muhammad Rofi'i'1, Ikhsan Maksum² \\ ${ }^{1}$ Fakultas Ekonomi dan Bisnis Universitas YARSI, Jakarta Pusat, DKI Jakarta \\ ${ }_{2}^{2}$ Fakultas Ekonomi Universitas Islam Negeri Maulana Malik Ibrahim, Malang, Indonesia
}

\begin{tabular}{l}
\hline Info Article \\
\hline History Article: \\
Submitted: 27 August 2020 \\
Revised: 23 September 202 October 2020 \\
Accepted: 16 Oywords: \\
Kenwisi, Manajer Pembelian, \\
Pengambilan Keputusan, \\
Manufaktur
\end{tabular}

\begin{abstract}
Abstrak
Meskipun penggunaan intuisi telah menjadi salah satu alat pengambilan keputusan yang disukai oleh CEO, manajer dan profesional, studi tentang bagaimana penggunaan intuisi dinilai di tempat kerja masih langka di literatur. Artikel ini bermaksud untuk mengatasi kesenjangan literatur ini dengan berbagi temuan tentang pentingnya penggunaan intuisi dan manifestasi praktisnya dalam profesi dari sudut pandang 85 manajer pembelian. Data menunjukkan bahwa intuisi sebagian besar dikenal sebagai: (1) kapasitas untuk membuat keputusan yang tepat melalui pengenalan pola; (2) kapasitas untuk membuat keputusan cepat; dan (3) kemampuan bernalar menggunakan pengalaman. Temuan penelitian membuktikan bahwa penggunaan intuisi dihargai tidak hanya sejauh berkontribusinya pada kesuksesan sebuah pengambilan keputusan, tetapi juga untuk peningkatan kemampuan pribadi. Sayangnya, peserta dalam penelitian ini cenderung berbagi gagasan umum dan ambigu tentang pentingnya intuisi daripada menyajikan contoh kehidupan profesional berbasis praktik yang konkret yang menggambarkan pemahaman dan penerapannya dalam organisasi mereka.
\end{abstract}

\section{How is The Use of Intuition Valued by Purchasing Managers? A Study Based on The Perspective of Manufacturing Industries' Employees}

\begin{abstract}
Although the use of intuition has become one of the preferred decision-making tools by CEOs, managers and professionals alike, studies of how the use of intuition is valued in the workplace is scarce in the literature. This article intends to address this literature gap by sharing findings on the importance of using intuition and its practical manifestations in the profession from the point of view of purchasing managers. The data show that intuition is largely known as: (1) the capacity to make informed decisions through pattern recognition; (2) the capacity to make quick decisions; and (3) the ability to reason using experience. The research's findings prove that the use of intuition is valued not only insofar as it contributes to the success of a decision making, but also to the enhancement of personal abilities. Unfortunately, participants in this study tended to share general and ambiguous ideas about the importance of intuition rather than present concrete, practice-based examples of professional life that illustrate their understanding and application in their organizations.
\end{abstract}

How to Cite: Gani, A., N., Rofi'i, M., \& Maksum, I. (2020). Bagaimana Penggunaan Intuisi Dinilai Oleh Manajer Pembelian? Sebuah Studi

Berdasarkan Perspektif Karyawan Manufaktur. Ekonomi Bisnis, 25 (2), 95-107 
Penelitian pembelian secara tradisional mencirikan proses pengambilan keputusan sebagai proses analitis, atau rasional, yang mencakup pengumpulan informasi ekstensif dan analisis rinci (Riedl, Kaufmann, Zimmermann, \& Perols, 2013). Misalnya, literatur pemilihan pemasok yang komprehensif, yang dapat dikelompokkan ke dalam dua kategori utama (Carter Craig, Kaufmann, \& Michel, 2007; Igarashi, de Boer, \& Fet, 2013) - (1) kriteria pemilihan (mis., Choi \& Hartley, 1996; Sharland, Eltantawy, \& Giunipero, 2003) dan (2) model keputusan (mis., de Boer \& van der Wegen, 2003; Singh, 2014) biasanya mengasumsikan perilaku rasional.

Namun, dalam praktiknya, peningkatan volatilitas dan kompleksitas eksternal, di satu sisi, dan tekanan waktu internal serta kendala sumber daya di sisi lain, membuat pengumpulan, penataan, dan analisis data secara ekstensif sebelum membuat keputusan pembelian seringkali sulit atau bahkan tidak mungkin (Ellis, Henry, \& Shockley, 2010; Mantel, Tatikonda, \& Liao, 2006).

Hal ini membuat keefektivan pembuatan keputusan dalam konteks pembelian menjadi sangat sulit dicapai. Terdapat beberapa faktor yang mempengaruhi tingkat efektifitan ini, diantaranya: informasi yang terkadang berubah ubah (Carter Craig et al., 2007); kondisi tekanan waktu yang tinggi saat harus membuat keputusan (Riedl et al., 2013); risiko bisnis yang tinggi apabila membuat keputusan yang salah (Choi \& Hartley, 1996).

Definisi efektivitas pengambilan keputusan menyiratkan bahwa keputusan terkadang menghasilkan hasil yang tidak diinginkan, karena hasil yang baik ditentukan tidak hanya oleh efektivitas proses pengambilan keputusan, tetapi juga oleh faktor lain yang tidak dapat dikontrol (misalnya, dinamika eksternal). Definisi efektivitas pengambilan keputusan juga menunjukkan bahwa jika pembuat keputusan (misalnya, manager pembelian) mengikuti proses pengambilan keputusan yang paling efektif dalam kondisi yang menantang, kemungkinan keputusan mereka menghasilkan hasil yang positif akan meningkat secara probabilistik.

Di seluruh konteks pengambilan keputusan, ada perbedaan yang signifikan dalam karakteristik tugas pengambilan keputusan. Kami menyatakan sebelumnya bahwa tugas keputusan pembelian adalah masalah keputusan yang ditandai dengan berbagai tantangan: lingkungan yang tidak pasti dan dinamis, tingkat risiko yang tinggi, dan tekanan waktu yang signifikan untuk membuat keputusan (Baron, 2008; Busenitz \& Barney, 1997; Mullins \& Forlani, 2005; Rosenbusch, Rauch, \& Bausch, 2011). Berdasarkan literatur yang ada, konstruksi berikut menggambarkan karakteristik tugas keputusan terkait pembelian di manajemen operasional: dinamisme lingkungan, ketidakpastian lingkungan, situasi berisiko tinggi, dan tekanan waktu yang signifikan. Efek negatif dari konstruksi ini pada proses pengambilan keputusan sudah mapan dalam literatur.

Dinamisme lingkungan mengacu pada tingkat perubahan dalam hubungan antara fakta dan variabel (Dess \& Beard, 1984). Sebuah studi menggunakan simulasi pengambilan keputusan lingkungan menemukan bahwa dinamisme lingkungan dapat mengurangi kinerja pengambilan keputusan strategis karena pembuat keputusan tidak dapat atau lambat merespon situasi yang berubah. Ketidakpastian lingkungan mengacu pada situasi di mana kemungkinan hasil tidak diketahui, dan pembuat keputusan tidak dapat memprediksi perkembangan secara akurat karena kurangnya informasi berkualitas tinggi (Lipshitz \& Strauss, 1997).

Riset sebelumnya telah menemukan bahwa tingkat ketidakpastian yang tinggi mengurangi kecepatan pengambilan keputusan strategis. Risiko tinggi dapat menyebabkan keragu-raguan dalam pengambil keputusan 
mengenai strategi pemrosesan informasi mana yang harus digunakan untuk meningkatkan efektivitas pengambilan keputusan (Palich \& Ray Bagby, 1995). Tekanan waktu yang signifikan dapat mengganggu kualitas keputusan (Chu \& Spires, 2001). Tekanan waktu yang signifikan juga dapat menghambat proses pengambilan keputusan karena kurangnya informasi berkualitas tinggi (Gani, Van Riel, Streukens, \& Größler, 2020).

Berdasarkan latar belakang tersebut, banyak literatur yang berakar pada kognitif psikologi, yang menunjukkan bahwa individu dibatasi secara rasional, menggunakan heuristik untuk pengambilan keputusan, dan menderita bias sistematis (Bendoly, Croson, Goncalves, \& Schultz, 2010). Manajemen operasi perilaku yang masih baru lahir dan aliran manajemen pasokan perilaku yang lebih spesifik oleh karena itu berpendapat bahwa perspektif perilaku juga diperlukan untuk disiplin manajemen rantai pasokan (Bendoly et al., 2010; Carter Craig et al., 2007; Gino \& Pisano, 2008). Temuan terbaru dari penelitian penilaian dan pengambilan keputusan manusia umum lebih lanjut menunjukkan perlunya menyelidiki baik risiko dan manfaat dari penggunaan mode pengambilan keputusan nonrasional, seperti intuisi (Kahneman \& Klein, 2009).

Banyak literatur di bidang kognitif psikologi yang menyetujui bahwa penggunaan kognitif yang intuitif dalam proses pengambilan keputusan dapat melengkapi penggunaan proses kognitif yang rasional (Evans, 2010). Proses kognitif intuitif dapat menghasilkan keputusan yang cepat dan efisien (Epstein, Pacini, DenesRaj, \& Heier, 1996). Penelitian juga menemukan bahwa pengambilan keputusan akan menjadi lebih efektif dengan menggunakan proses yang intuitif saat menghadapi situasi dengan ketidakpastian yang tinggi (Khatri \& Ng, 2000). Hal ini membuat proses pengambilan keputusan yang intuitif telah diakui menjadi salah satu alat dalam proses pengambilan keputusan yang efektif (Dane \& Pratt, 2007).

Para peneliti kognitif psikologi telah setuju bahwa penggunaan intuisi dalam pengambilan keputusan strategik dapat membantu manajer dalam menghadapi situasi yang sulit dan juga mengambil keputusan yang efektif. Banyak studi (contoh: Mueller \& Shepherd, 2016; Sadler-Smith, 2004) yang telah menemukan bahwa pengambilan keputusan dibawah situasi dengan tingkat ketidakpastian yang tinggi dapat menjadi lebih efektif dengan menggunakan proses yang intuitif. Penggunaan intuisi juga membuat seseorang lebih efektif dalam membuat keputusan yang kreatif dan inovatif.

Dalam teori manajemen operasi, pertanyaan apakah pengambilan keputusan seperti pembelian lebih baik dilakukan dengan menggunakan proses yang rasional atau intutif telah menjadi salah satu fokus perdebatan yang inten. Di satu sisi, penggunaan proses yang rational sepertinya menjadi pilihan yang paling logis dikarenakan proses pengambilan keputusan pada bidang manajemen operasi banyak menggunakan data dan angka. Akan tetapi pada sisi lain, kemampuan seseorang, contohnya manajer pembelian, dalam menggunakan pengalamannya dan kemampuannya untuk membuat keputusan yang cepat menjadi sangat penting dalam memastikan kelancaran proses produksi. Oleh karena itu, penggunaan intuisi mempunyai peran yang penting dalam meningkatkan keefektivan proses pengambilan keputusan yang dilakukan oleh manajer pembelian.

Meskipun penggunaan intuisi semakin diperdebatkan di dunia praksi manajemen operasional (contohnya pengambilan keputusan pembelian), banyak penelitian di literatur tidak mempertimbangkan perspektif praktisi lapangan seperti manajer pembelian. Studi empiris yang bertujuan untuk mengkarakterisasi bagaimana 
penggunaan intuisi dibutuhkan, dipahami dan diterapkan di tempat kerja masih cukup langka. Dalam konteks pembelian di suatu proses manajemen produksi, penggunaan intuisi sangat penting untuk menangani lingkungan bisnis yang berubah dengan cepat dimana keputusan yang tidak akurat dan pemikiran yang tidak masuk akal dapat menyebabkan krisis keuangan.

Untuk mengatasi kesenjangan pada literatur terkait dengan penggunaan intuisi oleh para manajer, artikel ini menyajikan studi penelitian eksplorasi kualitatif yang meneliti persepsi pribadi, kepercayaan dan pengalaman manajer pembelian dari industri manufaktur tentang penggunan intuisi. Oleh karena itu, penelitian ini mencoba menjawab pertanyaan bagaimana pengunaan intutisi dinilai oleh praktisi dalam proses manajemen pembelian. Interpretasi dan tema yang berbeda meuncul dari data yang membantu menggambarkan dengan lebih baik pemahaman dan eskpresi penggunaan intuisi dalam manajemen operasional khususnya terkait pembelian. Studi ini dimaksudkan untuk mendukung praktisi pembelian dalam implementasi penggunaan intuisi dalam praktek kerja sehari-hari.

Studi eksplorasi yang kami lakukan ini juga memberikan kontribusi teoritis kepada literatur pengambilan keputusan pembelian. Secara khusus, studi ini memperluas definisi penggunaan intuisi dalam konteks manajemen operasi, khususnya untuk para manajer pembelian di industri manufaktur. Studi ini memperlihatkan bahwa penggunaan intuisi tidak hanya dinilai sebagai bagian kemampuan kognitif tetapi juga sebagai bagian dari pengembangan kemampuan pribadi.

\section{METODE}

Penelitian ini menggunakan Focus Group Discussion (FGD), mengikuti prosedur yang telah dilakukan sebelumnya oleh (Onwuegbuzie, Johnson, \& Collins,
2009). Metode ini bertujuan untuk mengunpulkan data tentang pandangan manajer pembelian tentang penggunann intuisi dalam proses pengambilan keputusan. Peserta diskusi diminta untuk berbagi pendapat dan pengalaman pribadi tentang penggunaan intuisi saat mereka membuat keputusan strategic terkait pembelian di tempat kerja. Metode ini dipilih karena dapat menghasilkan volume data yang banyak dalam waktu yang relative singkat, serta memperoleh materi yang kaya dan menarik dari hasil interaksi kelompok yang intens (Penkauskiené, Railienè, \& Cruz, 2019).

Secara total, 17 FGD dilaksanakan antara November 2019 dan Januari 2020, melibatkan 85 manajer pembelian dari berbagai industri manufaktur. FGD dilaksanakan pada acara workshop dan pelatihan supply chain management. Salah satu aktivitas pada acara workshop tersebut adalah berdiskusi terkait pengambilan keputusan yang efektif. Setiap kelompok FGD terdiri dari dari lima peserta. Rata-rata durasi diskusi adalah 35 menit (min $=23$ menit; $\max =57$ menit). Kelompok terdiri dari 60 laki-lai dan 25 perempuan dengan rentang usia 24 dan 45 tahun. Partisipan mencakup 6 industri: otomotif; makanan; minuman; percetakan; elektronik; dan garmen. Dengan sampel heterogen seperti itu, dimungkinkan untuk mengungkap keragaman fenomena yang diteliti.

FGD dilakukan dengan menggunakan empat pertanyaan panduan: satu pertanyaan pembuka dan tiga pertanyaan analisis. Pertanyaan pembuka adalah: seberapa penting penggunaan intuisi dalam proses pengambilan keputusan di pekerjaan Anda? Pertanyaan analisis adalah sebagai berikut: (1) Apakah penggunaan intuisi membantu dalam pekerjaan Anda? (2) Apakah kemampuan untuk berintuisi adalah suatu skill yang penting saat di pekerjaan Anda? (3) Apa saja manfaat yang Anda dapat dengan menggunakan intuisi dalam membuat keputusan?

Analisis data dimulai dengan transkripsi rekaman audio. Peneliti membuat transkripsi dan memulai proses analisis data segera setelah sesi 
kelompok berakhir. Setiap percakapan peserta diberi kode sesuai dengan sistem yang disepakati (nomer peserta_gender_sektor industri) dan berfungsi untuk analisis data dan kerahasian peserta.

Transkrip dianalisis menggunakan analisis tematik (Braun \& Clarke, 2006) karena kesesuaiannya untuk meringkas fitur utrama dari kumpulan data yang luas dan kemungkinan menghasikan wawasan yang tidak terduga. Proses analisis data terdiri dari pembacaan berulang setiap transkrip sampai semua teks yang relevan dikategorikan dan semua tema dibandingkan satu sama lain. Data yang dikategorikan kemudian dinamai menjadi tema yang relevan (Braun \& Clarke, 2006).

\section{PEMBAHASAN}

Bagian ini menyajikan temuan utama mengenai pentingnya penggunaan intuisi untuk pengambilan keputusan dari berbagai manajer pembelian.

Tiga tema utama muncul dari data dan disajikan secara terpisah, meskipun interaksi mereka memberikan gambaran umum tentang pemahaman terkait penggunaan intuisi dalam konteks manajemen operasi. Data menunjukkan bahwa penggunaan intuisi sebagian besar dinilai sebagai: (1) kapasitas untuk membuat keputusan yang tepat melalui pengenalan pola; (2) kapasitas untuk membuat keputusan cepat; dan (3) kemampuan bernalar menggunakan pengalaman. Sajian ikhtisar singkat dari temuan penelitian terlihat pada Gambar 1 yang menunjukkan aspek umum dan kekhasan dari pendapat para manajer pembelian.
Penjelasan mengenai tiap tema utama penggunaan intuisi oleh manajer pembelian akan dijelaskan secara berurutan sebagai berikut.

\section{Intuisi sebagai kapasitas untuk membuat keputusan melalui pengenalan pola}

Kapasitas untuk membuat keputusan melalui pengenalan pola terkait langsung dengan definisi intuisi di literatur kognitif psikologi. Menurut para partisipan, ada cara konkret untuk mengambil keputusan dengan menggunakan intuisi. Salah atunya adalah menggunakan dan menpraktikan keterampilan interpretasi berdasarkan informasi tacit yang sudah ada di benak individu. Mereka menggunakan informasi ini untuk mengaitkan masalah yang ada di depan mata. Mereka mencari pola kesamaan atas masalah yang sekarang dengan masalah yang sudah lalu.

Aspek ini diungkapkan oleh partisiapan dari semua sektor industri. Partisipan menggarisbawahi bahwa penting untuk mengetahui bagaimana memecabkan masalab pembelian stok barang berdasarkan pengalaman sebelumbelumnya' [39_L_OTO]; bahwa 'keputusan sebelumnya adalah suatu basis data yg perlu diperbatikan' [14_L_FOD]; bahwa 'memuntuskan berapa barang yang perlu dibeli adalah proses yang berkaitan dengan keputusan yang dulu pernah terjadi' [58_P_PRT].

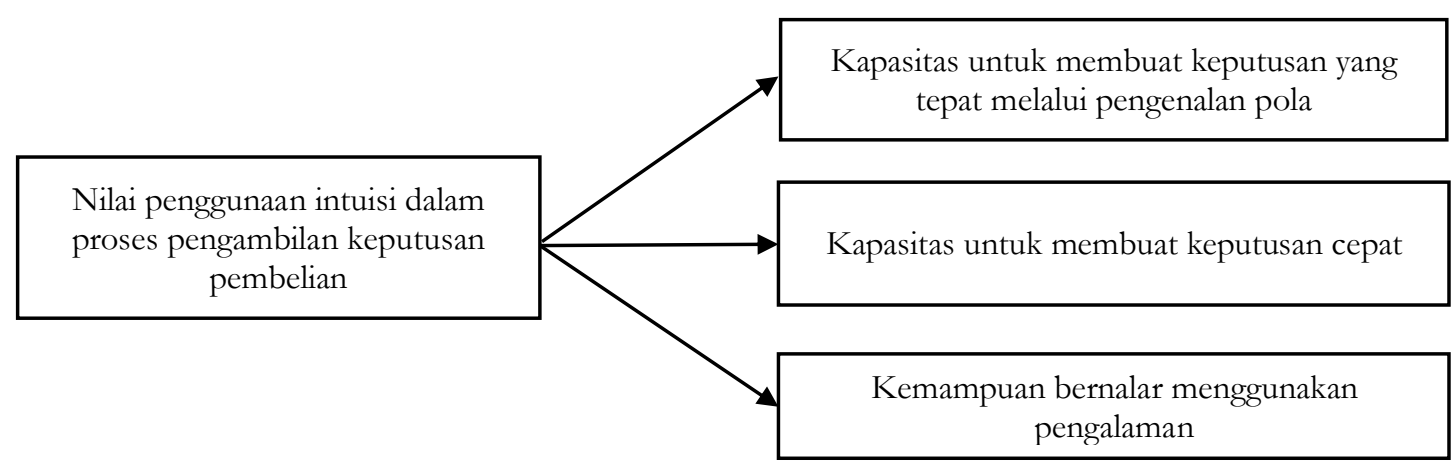

Gambar 1. Nilai Penggunaan Intuisi berdasarkan Persepsi Manajer Pembelian 
Interpretasi ini diperlakukan tidak hanya secara lokal, tetapi juga secara holistik.

Cara lain untuk menggunakan intuisi dengan pengenalan pola adalah dengan mengingat-ingat beberapa titik acuan pada keputusan terdahulu. Kerampilan ini penting karena 'membeli barang ... membutubkan menganalisa data pembelian yang sudab - sudab' [11_L_OTO]. Partisipan juga menekankan bahwa 'info dari orang lain yang kita ingat ... penting untuk dijadikan pertimbangan' [67_L_GRM]. Hal ini berarti peran informasi yang tersimpan dibenak seseorang menjadi penting saat menggunakan intuisi.

Banyak contoh yang diungkapkan oleh partisipan mencerminkan intuisi tidak hanya sebagai disposisi, tetapi sebagai bagian dari analisis keterampilan yang kompleks dan sintesis dari berbagai sudut pandang, sumber informasi, interpretasi pesan yang terlihat dan tersembunyi, evaluasi argumen dan kemungkinan skenario.

Kualitas argumen bergantung pada bukti, diperiksa dalam konteks konkret atau lebih luas. Mengecek argumen satu sama lain berarti bersiapsiap membuat keputusan. Dan bukan hanya pengetabuan saya sendiri, tapi juga milik orang lain. Bagaimana lagi kita bisa memahami informasi yang benar dan yang tidak menjadi sangat penting '[62_L_OTO]. Secara umum, argumentasi yang masuk akal muncul sebagai hasil dari upaya manajer yang bertujuan dan sistematis untuk menghasilkan ide dan keputusan yang jelas dan umum. Dalam kasus seperti itu, manajer harus dapat menjelaskan bagaimana keputusan diambil: 'Saya melihat situasi dan kondisi, lalu juga pola - pola sebelumnya dalam membangun solusi, jadi saya punya alasan untuk menjelaskan keputusan ini kepada orang lain' [5_L_BVG].

Pernyataan-pernyataan dari partisipan tersebut menunjukan bahwa penggunaan intuisi adalah sebagai alat untuk membuat keputusan melalui pengenalan pola baik dari informasi yang explisit atau yang tacit. Hal ini terlihat dari penggunaan informasi terdahulu, pengetahuan dari orang lain, keputusan terdahulu sebagai sumber informasi yang relevan bagi manajer pembelian untuk utilisasi penggunaan intuisi.

\section{Intuisi sebagai kapasitas untuk membuat keputusan yang cepat}

Kapasitas untuk membuat keputusan yang cepat juga terkait langsung dengan definisi intuisi di literatur kognitif psikologi. Menurut para partisipan, penggunaan intuisi saat harus mengambil keputusan di situasi yang rumit dan penuh tekanan waktu menjadi sangat penting. Hal ini dikarenakan penggunaan intuisi dalam situasi tersebut dapat mempercepat proses pengambilan keputusan. Walaupun tidak selamanya keputusan yang diambil akan menghasilkan outcome yang positif, proses pengambilan keputusan yang cepat dapat membuka jalan kepada informasi yang baru dan relevan.

Manajer pembelian mengakui bahwa mereka beroperasi dibawah kondisi dengan tekanan waktu yang tinggi dan juga ketidakpastian. Hal ini membuat penggunaan intuisi menjadi berguna dalam pekerjaan mereka sehingga 'dapat membuat keputusan sebelum barang dari supplier babis' [59_P_OTO]. Mereka menghadapi ketidakpastian dengan menggunakan gut-feeling saat mengambil keputusan karena 'Saya tidak tahu kapan barang akan sampai jadi kadang - kadang saya order barang dengan feeling saya saja' [33_P_FOD]. Kondisi pekerjaan mereka membuat penggunaan intuisi menjadi berharga untuk dapat membuat keputusan yang cepat dan memastikan kelancaran produksi dan juga bisnis perusahaan.

Partisipan juga menekankan bahwa penggunaan intuisi membuat mereka lebih berani mengambil keputusan. Intuisi membuat mereka lebih berani berinisiatif dalam pekerjaan karena 'saya yakin dengan keputusan saya kearena dikepala saya ini susah sesuai dengan dulu - dulu' [47_L_PRT]. Manajer dengan pengalaman yang lama akan lebih berani menggunakan gut-feeling mereka dapat mengambil keputusan. Hal ini terlihat dari bagaimana mereka percaya kepada kemampuan intuisi mereka: Saya sudah pernah menghadapi situasi seperti ini sebelumnya dan 
feeling saya mengatakan bahwa hal yang sama akan terjadi lagi. Jadi saya order barangnya jaub-jauh hari' [28_L_ELE].

Contoh pernyataan-pernyataan di atas dari partisipan menunjukkan bahwa penggunaan intuisi adalah sebagai alat untuk membuat keputusan yang cepat. Penggunaan intuisi dapat membantu pengambil keputusan saat dihadapi dengan situasi yang penuh ketidakpastian dan juga tekanan waktu yang tinggi. Untuk lebih lengkap contoh-contoh pernyataan manajer pembelian terkait nilai penggunaan intuisi terangkum dalam Tabel 1.

\section{Intuisi sebagai kemampuan bernalar menggunakan pengalaman}

Intuisi juga dinilai sebagai sebuah kemampuan bernalar menggunakan pengalaman. Hal ini tidak jauh dari definisi intuisi itu sendiri. Menurut partisipan, pengalaman yang mereka raih dari bekerja telah memberikan informasi yang relevan terkait proses pengambilan keputusan terkait dengan pembelian. Pengalaman ini membuat mereka dapat dengan cepat memberikan umpan balik terkait masalah yang mereka sedang hadapi.

Manajer pembelian mengkaitkan penggunaan intuisi dengan pengalaman yang mereka miliki, seperti kedua tidak dapat dipisahkan. Partisipant mengungkapkan bahwa mereka merasa lebih nyaman membuat keputusan yang didasari oleh informasi dari pengalaman terdahulu: 'Saya dapat membuat keputusan dengan cepat dengan mengacu kepada pengalmaan saya sebelumnya. Saya lebih percaya diri dengan keputusan saya saat saya tabu saya sudah pernah melakukannya' [71_P_FOD].

Peran tingkat pengalaman juga mempengaruhi keefektifan penggunaan intuisi. Partisipan menggarisbawahi bahwa pengalaman saya yang masih sedikit membuat saya kadang - kadang tidak dapat membuat keputusan yang saya nilai baik' [57_L_ELE]. Hal ini menunjukan seseorang akan lebih percaya gut-feeling mereka saat mereka juga mempunyai tingkat pengalaman yang tinggi. Oleh karena itu, seseorang perlu membangun pengalaman itu penting untuk dapat membuat keptusan yang cepat dan

Tabel 1. Contoh Pernyataan Manajer Pembelian Terkait Nilai Dari Penggunaan Intuisi

\begin{tabular}{|c|c|c|}
\hline No & Persepsi manajer terhadap intuisi & Contoh pernyataan \\
\hline 1. & $\begin{array}{l}\text { Kapasitas untuk membuat keputusan yang } \\
\text { tepat melalui pengenalan pola }\end{array}$ & $\begin{array}{l}\text { - 'bagaimana memecahkan masalah pembelian stok } \\
\text { barang berdasarkan pengalaman sebelum-belumnya' } \\
\text { [39_L_OTO] } \\
\text { - 'memutuskan berapa barang yang perlu dibeli adalah } \\
\text { proses yang berkaitan dengan keputusan yang dulu } \\
\text { pernah terjadi' [58_P_PRT] }\end{array}$ \\
\hline 2. & Kapasitas untuk membuat keputusan cepat & $\begin{array}{l}\text { - 'dapat membuat keputusan sebelum barang dari } \\
\text { supplier habis' [59_P_OTO] } \\
\text { - } S \text { _aya tidak tahu kapan barang akan sampai jadi kadang } \\
\text { - kadang saya order barang dengan feeling saya saja' } \\
\text { [33_P_FOD] }\end{array}$ \\
\hline 3. & $\begin{array}{l}\text { Kemampuan bernalar menggunakan } \\
\text { pengalaman }\end{array}$ & $\begin{array}{l}\text { - 'Saya lebih percaya diri dengan keputusan saya saat saya } \\
\text { tahu saya sudah pernah melakukannya' [71_P_FOD] } \\
\text { - } \quad \text { pengalaman saya yang masih sedikit membuat saya } \\
\text { kadang - kadang tidak dapat membuat keputusan yang } \\
\text { saya nilai baik' [57_L_ELE] }\end{array}$ \\
\hline
\end{tabular}


juga yang bagus ... pengalaman dapat membantu saat informasi tidak tentu' [59_L_ELE].

Contoh pernyataan-pernyataan diatas dari partisipan menunjukan bahwa penggunaan intuisi sangat berkaitan dengan kemampuan bernalar menggunakan pengalaman. Tingkat pengalaman yang tinggi akan membuat seserorang lebih dapat bernalar dan percaya diri dengan intuisi mereka.

\section{Implikasi penelitian}

Hasil temuan penelitian ini memberikan beberapa implikasi secara teoritis. Pertama, hasil temuan ini mengkonfirmasi beberapa aspek yang terdapat pada definisi intuisi. Penggunaan pengalaman dan juga pengenalan pola telah lama menjadi inti dari definisi intuisi di literatur kognitif psikologi. Oleh karena itu, penilaian intuisi oleh manajer pembelian ini sejalan dengan definisi intuisi yang ada di literatur.

Kedua, temuan pada penelitian ini juga mengkonfirmasi argumen di literatur riset operasional terkait penggunaan proses pengambilan keputusan yang intutif akan meningkatkan keefektivan proses tersebut. Hal ini membuat penggunana intuisi menjadi sangat relevan di konteks pembelian atau konteks rantai pasok.

Penelitian ini juga memberikan beberapa implikasi praktis. Pertama, menjadi bahan pelatihan untuk manajer pembelian agar memasukkan atau harus mengintegrasikan penggunaan proses rational/analisis dengan intuisi dalam aktivitas majerial, terutama dalam pengambilan keputusan pembelian. Penggabungan ini akan membuat manajer pembelian lebih cepat belajar mempraktekkan dan menajamkan intuisi mereka sehingga mereka mampu menggunakan intuisi mereka secara efektif di dunia kerja mereka. Sehingga, mereka akan menjadi individu pengambil keputusan yang lebih baik.

Implikasi praktik yang kedua adalah terkait pendidikan di tingkat universitas. Mata kuliah manajemen operasi di tingkat universitas sebaiknya telah memasukkan materi pengambilan keputusan yang efektif berdasarkan penggunaan kognitif. Pembelajaran terkait penggunaan rasional dan intuisi secara efektif di tingkat universitas akan sangat membantu calon pekerja dalam membuat keputusan yang baik.

Implikasi praktis penelitian berikutnya adalah terkait dengan agenda penelitian selanjutnya yang bisa dilakukan. Pertama, penelitian mendatang diperlukan untuk mempelajari mekanisme kognitif yang mendasari efektivitas pengambilan keputusan dalam konteks pembelian di manajemen operasi. Ada kesepakatan bahwa pengambil keputusan tersebut memiliki pendekatan unik untuk pengambilan keputusan karena kemampuan bawaan atau yang dipelajari (Alvarez \& Barney, 2004) untuk menghadapi tingkat ketidakpastian, ambiguitas dan tekanan waktu dan tekanan emosional yang tinggi. Namun, proses pengambilan keputusan diperlukan untuk penciptaan, kesuksesan, meminimalkan risiko, dan kelangsungan bisnis. Oleh karena itu, penting untuk mengeksplorasi hubungan antara berbagai bentuk perilaku psikologis dalam mencapai efektivitas pengambilan keputusan (Van Riel \& Horvath, 2014).

Kedua, penelitian lanjutan perlu dilakukan untuk menilai dampak penggunaan aktual dari intuisi dan/atau rasionalitas untuk pengambilan keputusan pada ukuran hasil yang terkait dengan pembelian di konteks rantai pasok. Sebagaimana terungkap dalam tinjauan terbaru oleh (Baldacchino, Ucbasaran, Cabantous, \& Lockett, 2015) masih sangat sedikit penelitian yang menyelidiki penggunaan intuisi untuk pengambilan keputusan di konteks pembelian. Sebagian besar studi yang ada dalam literatur telah difokuskan pada preferensi manajer untuk intuisi dan/atau rasionalitas. Kami menyarankan bahwa penelitian berfokus pada penggunaan intuisi dan rasionalitas yang sebenarnya dapat menambah pengetahuan mengenai pendorong efektivitas pengambilan keputusan.

Ketiga, penelitian selanjutnya sebaiknya menyelidiki pertanyaan seperti bagaimana intuisi dan rasionalitas bekerja bersama-sama? Penelitian 
sebelumnya menunjukkan bahwa keefektifan pengambilan keputusan di bawah tekanan waktu yang signifikan dan ketidakstabilan lingkungan yang rendah dapat dicapai dengan menggunakan intuisi dan rasionalitas (Allinson \& Hayes, 1996; Kickul, Gundry, Barbosa, \& Whitcanack, 2009). Akan tetapi, hal ini tidak dapat memberikan bukti tentang bagaimana kedua sistem ini bekerja sama. Oleh karena itu, diperlukan penelitian untuk mengamati pengaruh peningkatan dari proficiency pada struktur saraf yang berkaitan dengan proses mental intuisi dan rasionalitas. Penelitian semacam itu akan memberikan wawasan tentang mekanisme otak yang mengatur dan mengelola intuisi dan rasionalitas. Wawasan ini dapat digunakan untuk menghasilkan bukti kuat tentang bagaimana intuisi dan rasionalitas bekerja bersama-sama dalam mencapai efektivitas pengambilan keputusan.

Kempat, peneliti berikutnya (tidak hanya psikolog dan ilmuwan kognitif) yang tertarik untuk menyelidiki pengambilan keputusan dalam keadaan sulit untuk mulai mengeksplorasi pendekatan untuk mengukur mekanisme mengenai penggunaan intuisi yang sebenarnya dengan cara yang lebih objektif, khususnya dalam kaitannya dengan apa yang terjadi dengan tubuh pembuat keputusan dan otak. Misalnya, para sarjana dapat memeriksa otak pembuat keputusan yang terus-menerus harus menghadapi keadaan sulit dengan menggunakan MRI fungsional (fMRI) atau Electroencephalography (EEG) untuk mencari tanda saraf intuisi. Para sarjana juga dapat menggunakan elektrokardiogram (EKG) untuk pengukuran variabilitas detak jantung (perlambatan/akselerasi detak-ke-detak) untuk memeriksa hubungan antara gut-feeling dan intuisi.

Kelima, temuan dari penelitian sebelumnya menunjukkan fakta bahwa beberapa proses pengambilan keputusan mengarah pada efektivitas pengambilan keputusan dan lainnya mengarah pada ketidakefektifan. Seperti yang diakui oleh (Dane \& Pratt, 2007), penggunaan intuisi mungkin juga memiliki sisi negatif. Oleh karena itu, penelitian juga diperlukan untuk menyelidiki penyebab ketidakefektifan pengambilan keputusan dalam keadaan sulit. Penelitian semacam itu tidak hanya akan memberikan wawasan tentang gambaran "tidak lengkap" dari anteseden efektivitas pengambilan keputusan tetapi juga akan memiliki implikasi praktis yang signifikan dalam kaitannya dengan pengambilan keputusan kewirausahaan, manajerial, dan strategis.

\section{SIMPULAN DAN SARAN}

Temuan penelitian ini mengungkapkan interpretasi yang cukup luas dari penggunaan intuisi dan perannya dalam praktik profesional. Sangat mengejutkan di sini bahwa manajer pembelian menyerukan banyak atribut yang sejalan dengan definisi intuisi di literatur kognitif psikologi. Beberapa atribut yang mereka cari dalam lingkup ini adalah: pemecahan masalah, keterampilan komunikasi, penilaian klinis, toleransi terhadap ketidakpastian dan kreativitas.

Secara umum, intuisi dipahami tidak hanya sebagai keterampilan kognitif dan/atau disposisi, tetapi juga sebagai pengambilan posisi kritis dan aktif, inisiatif pribadi dan tanggung jawab sosial. Hal ini sesuai dengan beberapa argumen di literatur kognitif psikologi (Gani et al., 2020; Sadler-Smith, 2004). Dengan demikian, penggunaan intuisi termasuk dalam keterampilan kognitif yang saling bergantung (misalnya pengaturan diri, evaluasi, interpretasi) dan elemen disposisi (misalnya analisitas, sistematisitas, pikiran terbuka) yang memungkinkan para profesional untuk mengantisipasi dan bersiap untuk situasi apa pun, serta untuk mengatur dan memantau pemikiran dan perilaku mereka sendiri dalam proses tersebut.

Ada keterbatasan dalam penelitian ini. Dalam penelitian eksplorasi kualitatif saat ini, batasan metodologi yang berbeda dapat diidentifikasi yang mungkin memiliki dampak potensial pada temuan. Ini sebagian besar terkait dengan profil dan bahasa peserta penelitian. Meskipun para peneliti berusaha untuk memastikan representasi yang heterogen dalam hal profesi, usia, jenis kelamin, dan pengalaman kerja, representasi tersebut masih harus 
diperlakukan tidak merata untuk tujuan menghasilkan kesimpulan yang lebih umum. Peneliti berasumsi bahwa perbedaan angka (misalnya, representasi yang sangat tinggi dalam kelompok Ilmu Sosial dan sangat kecil dalam Ilmu Humaniora) tidak memungkinkan kesimpulan yang diambil untuk profesi dan bidang studi yang terpisah. Banyak ide yang tidak dimasukkan dalam fokus penelitian saat ini karena ringkas dan tidak adanya konteks.

Artikel ini bertujuan untuk mengkarakterisasi bagaimana penggunaan intuisi dipahami, dibutuhkan dan diekspresikan oleh manajer pembelian dari industri manufaktur. Interpretasi manajer pembelian tentang penggunaan intuisi terbagi menjadi tiga kategori utama: (1) kapasitas untuk membuat keputusan yang tepat melalui pengenalan pola; (2) kapasitas untuk membuat keputusan cepat; dan (3) kemampuan bernalar menggunakan pengalaman. Para manajer ini cenderung berbagi ide umum dan ambigu tentang pentingnya penggunaan intuisi daripada menyajikan contoh nyata kehidupan profesional berbasis praktik yang menggambarkan pemahaman dan penerapannya dalam organisasi mereka.

Para manajer pembelian juga memperlakukan intuisi sebagai kemampuan luas yang mencakup banyak hasil yang diinginkan seperti pengetahuan profesional yang baik, keterampilan sosial, dan ketahanan psikologis. Hal ini mengarah pada kesimpulan bahwa penggunaan intuisi bisa dikaitkan dengan banyak tujuan dan karakteristik profesional lain yang diinginkan. Ini adalah masalah serius, karena Ketika gagal membuat perbedaan yang tepat di sini berarti gagal memberikan bobot yang sesuai untuk intuisi itu sendiri. Dalam pengertian ini, penggunaan intuisi hanyalah salah satu dari banyak kemampuan manajemen yang perlu dikuasi oleh profesional, dan oleh karena itu harus dilatih dan dipelajari serta tercermin dan diterapkan dalam perencanaan kurikulum universitas sebagai kawah candradimuka calon profesional. Pembekalan kemampuan berintuisi sejak jenjang pendidikan tinggi melalui pilihan-pilihan mata kuliah dan pembelajaran bermuatan pengambilan keputusan secara rasional koqnitif dan intuitif, dapat membuat calon profesional lebih percaya diri dalam menggunakan pengalaman dan pengetahuan tacit mereka, terutama dalam pengambilan keputusan. Pemecahan kasus bisnis atau permainan (game) bisnis, bisa digunakan untuk mengasah kemampuan ini.

\section{UCAPAN TERIMA KASIH}

Terimakasih kepada Universitas YARSI yang telah memberikan dana penelitian untuk melakukan riset ini.

\section{DAFTAR RUJUKAN}

Allinson, C. W., \& Hayes, J. (1996). The Cognitive Style Index: A Measure of IntuitionAnalysis For Organizational Research. Journal of Management Studies, 33(1), 119$135 . \quad$ doi:10.1111/j.14676486.1996.tb00801.x

Alvarez, S. A., \& Barney, J. B. (2004). Organizing rent generation and appropriation: toward a theory of the entrepreneurial firm. Journal of Business Venturing, 19(5), 621-635. doi:https://doi.org/10.1016/i.jbusvent.2 $\underline{003.09 .002}$

Baldacchino, L., Ucbasaran, D., Cabantous, L., \& Lockett, A. (2015). Entrepreneurship Research on Intuition: A Critical Analysis and Research Agenda. International Journal of Management Reviews, 17(2), 212-231. doi:10.1111/ijmr.12056

Baron, R. A. (2008). The Role of Affect in the Entrepreneurial Process. Academy of Management Review, 33(2), 328-340. doi:10.5465/amr.2008.31193166

Bendoly, E., Croson, R., Goncalves, P., \& Schultz, K. (2010). Bodies of Knowledge for Research in Behavioral Operations. Production and Operations Management, 19(4), 
434-452.

doi:10.1111/j.1937-

5956.2009.01108.x

Braun, V., \& Clarke, V. (2006). Using thematic analysis in psychology. Qualitative Research in Psychology, 3(2), 77-101. doi:10.1191/1478088706qp063oa

Busenitz, L. W., \& Barney, J. B. (1997). Differences between entrepreneurs and managers in large organizations: Biases and heuristics in strategic decisionmaking. Journal of Business Venturing, 12(1), 9-30.

doi:https://doi.org/10.1016/S08839026(96)00003-1

Carter C., R., Kaufmann, L., \& Michel, A. (2007). Behavioral supply management: a taxonomy of judgment and decisionmaking biases. International Journal of Physical Distribution \& Logistics Management, 37(8), 631-669. doi:10.1108/09600030710825694

Choi, T. Y., \& Hartley, J. L. (1996). An exploration of supplier selection practices across the supply chain. Journal of Operations Management, 14(4), 333-343. doi:10.1016/S0272-6963(96)00091-5

Chu, P. C., \& Spires, E. E. (2001). Does Time Constraint on Users Negate the Efficacy of Decision Support Systems? Organizational Behavior and Human Decision Processes, $\quad 85(2), \quad$ 226-249. doi:https://doi.org/10.1006/obhd.2000. $\underline{2940}$

Dane, E., \& Pratt, M. G. (2007). Exploring Intuition and its Role in Managerial Decision Making. Academy of Management Review, 32(1), 33-54. doi:10.5465/amr.2007.23463682

de Boer, L., \& van der Wegen, L. L. M. (2003). Practice and promise of formal supplier selection: a study of four empirical cases. Journal of Purchasing and Supply Management, 9(3),

109-118.
doi:https://doi.org/10.1016/S14784092(03)00018-9

Dess, G. G., \& Beard, D. W. (1984). Dimensions of Organizational Task Environments. Administrative Science Quarterly, 29(1), 5273. doi: $10.2307 / 2393080$

Ellis, S. C., Henry, R. M., \& Shockley, J. (2010). Buyer perceptions of supply disruption risk: A behavioral view and empirical assessment. Journal of Operations Management, 28(1), 34-46. doi:https://doi.org/10.1016/i.jom.2009. $\underline{07.002}$

Epstein, S., Pacini, R., Denes-Raj, V., \& Heier, H. (1996). Individual Differences in Intuitive-Experiential and AnalyticalRational Thinking Styles. Journal of Personality \& Social Psychology, 71(2), 390405. doi:10.1037/0022-3514.71.2.390

Evans, J. S. B. T. (2010). Intuition and Reasoning: A Dual-Process Perspective. Psychological Inquiry, 21(4), 313-326. doi:10.1080/1047840X.2010.521057

Gani, A. N., Van Riel, A. C. R., Streukens, S., \& Größler, A. (2020). Investigating entrepreneurial use of intuition and rationality in decision-making: a QCA approachHandbook of Intuition Research as Practice. In. Cheltenham, UK: Edward Elgar Publishing.

Gino, F., \& Pisano, G. (2008). Toward a Theory of Behavioral Operations. Manufacturing \& Service Operations Management, 10(4), 676-691. doi:10.1287/msom.1070.0205

Igarashi, M., de Boer, L., \& Fet, A. M. (2013). What is required for greener supplier selection? A literature review and conceptual model development. Journal of Purchasing and Supply Management, 19(4), 247-263.

doi:https://doi.org/10.1016/i.pursup.20 $\underline{13.06 .001}$ 
Kahneman, D., \& Klein, G. (2009). Conditions for intuitive expertise: A failure to disagree. American Psychologist, 64(6), 515526. doi:10.1037/a0016755

Khatri, N., \& Ng, H. A. (2000). The Role of Intuition in Strategic Decision Making. Human Relations, 53(1), 57-86. doi:10.1177/0018726700531004

Kickul, J., Gundry, L. K., Barbosa, S. D., \& Whitcanack, L. (2009). Intuition versus Analysis? Testing Differential Models of Cognitive Style on Entrepreneurial SelfEfficacy and the New Venture Creation Process. Entrepreneurship Theory and Practice, 33(2), 439-453. doi:10.1111/j.15406520.2009.00298.x

Lipshitz, R., \& Strauss, O. (1997). Coping with Uncertainty: A Naturalistic DecisionMaking Analysis. Organizational Behavior and Human Decision Processes, 69(2), 149163.

doi:https://doi.org/10.1006/obhd.1997. $\underline{2679}$

Mantel, S. P., Tatikonda, M. V., \& Liao, Y. (2006). A behavioral study of supply manager decision-making: Factors influencing make versus buy evaluation. Journal of Operations Management, 24(6), 822-838. doi:https://doi.org/10.1016/i.jom.2005. $\underline{09.007}$

Mueller, B. A., \& Shepherd, D. A. (2016). Making the Most of Failure Experiences: Exploring the Relationship between Business Failure and the Identification of Business Opportunities. Entrepreneurship Theory and Practice, 40(3), 457-487. doi:10.1111/etap.12116

Mullins, J. W., \& Forlani, D. (2005). Missing the boat or sinking the boat: a study of new venture decision making. Journal of Business Venturing, 20(1), 47-69. doi:https://doi.org/10.1016/i.jbusvent.2 $\underline{003.08 .001}$
Onwuegbuzie, A. J., Johnson, R. B., \& Collins, K. M. (2009). Call for mixed analysis: A philosophical framework for combining qualitative and quantitative approaches. International Journal of Multiple Research Approaches, 3(2), 114-139. doi:10.5172/mra.3.2.114

Palich, L. E., \& Ray Bagby, D. (1995). Using cognitive theory to explain entrepreneurial risk-taking: Challenging conventional wisdom. Journal of Business Venturing, $\quad 10(6), \quad 425-438$. doi:https://doi.org/10.1016/08832026(95)00082-I

Penkauskienè, D., Railiené, A., \& Cruz, G. (2019). How is critical thinking valued by the labour market? Employer perspectives from different European countries. Studies in Higher Education, 44(5), 804-815. doi:10.1080/03075079.2019.1586323

Riedl, D. F., Kaufmann, L., Zimmermann, C., \& Perols, J. L. (2013). Reducing uncertainty in supplier selection decisions: Antecedents and outcomes of procedural rationality. Journal of Operations Management, 31(1), 24-36. doi:https://doi.org/10.1016/j.jom.2012. $\underline{10.003}$

Rosenbusch, N., Rauch, A., \& Bausch, A. (2011). The Mediating Role of Entrepreneurial Orientation in the Task EnvironmentPerformance Relationship: A MetaAnalysis. Journal of Management, 39(3), 633659. doi:10.1177/0149206311425612

Sadler-Smith, E. (2004). Cognitive Style and the Management of Small and Medium-Sized Enterprises. Organization Studies, 25(2), 155-181. doi:10.1177/0170840604036914

Sharland, A., Eltantawy, R. A., \& Giunipero, L. C. (2003). The Impact of Cycle Time on Supplier Selection and Subsequent Performance Outcomes. Journal of Supply 
Chain Management, 39(2), 4-12. doi:10.1111/j.1745-493X.2003.tb00155.x

Singh, A. (2014). Supplier evaluation and demand allocation among suppliers in a supply chain. Journal of Purchasing and Supply Management, 20(3), 167-176. doi:https://doi.org/10.1016/i.pursup.20 $\underline{14.02 .001}$

Van Riel, A. C. R., \& Horvath, C. (2014). Conceptualizing intuition as a mental faculty: toward a 'critique of intuitive reason' and a process model of intuition. Handbook of Research Methods on Intuition, 42-56. doi:Book_Doi

$10.4337 / 9781782545996$ 